Colistin by combined intramuscular and aerosol treatment failed completely in all patients. The patients treated successfully by Halliday (1967) appear to have had acute illnesses which were not, as in ours, superimposed upon chronic infections. Our results confirm previous impressions (Pines et al., 1963) that colistin has little or no place in the treatment of purulent exacerbations of chronic bronchitis.

\section{Summary}

Thirty-six trials of gentamicin were made in 23 patients suffering from chronic purulent bronchial infections. Pseudomonas pyocyanea and Klebsiella pneumoniae had been repeatedly isolated in profuse growth. The routes were intramuscular alone in medium and high doses, inhalation alone, and both combined. In only seven (19\%) did the treatment succeed.

Transient toxic effects were noted in only four patients with blood levels of $10 \mu \mathrm{g}$. or more and in a fifth patient given high doses, where levels were not measured.

Colistin in high doses was given by intramuscular injection and inhalation together to 17 patients; none benefited.
Acknowledgements are due to Mr. J. H. Weston, L.Inst.Biol., Nicholas Research Institute Ltd., for blood and sputum levels recorded; to Dr. Ross Renton and Mr. G. A. Poulter for supplies of Gentacin and for generous help ; and to the medical, nursing, and secretarial staff of Ware Park Hospital and the laboratory staff of Hertford County Hospital for their assistance.

\section{REFERENCES}

Barber, M., and Waterworth, P. M. (1966), Brit. med. 7., 1, 203.

Brayton, R. G., and Louria, D. B. (1964). Arch. intern. Med., 114, 205. Fraenkel, E. (1917). Z. Hyg., 84, 369.

Halliday, N. P. (1967). Clin. Traals 7. In press

Klein, J. O., Eickhoff, T. C., and Finland, M. (1964). Amer. F. med. $S c l ., 248,528$.

May, J. R. (1953). Lancet, 2, 534.

- (1954). Ibid., 2, 839.

Pierce, A. K., Edmonson, E. B., McGee, G., Ketchersid, J., Loudon, R. G., and Sanford, J. P. (1966). Amer. Rev. resp. Dis., 94, 309.

Pines, A., Bundi, R. S., Greenfield, J. S. B., and Plucinski, K. (1965), Brit. F. Dis. Chest, 59, 81.

- Lydon, T. J., Plucinski, K., and Barkley, H. (1963). Practitioner, 190,502 .

Reid, L. M. (1954). Lancet, 1, 275.

Stone, H. H., Martin, J. D., Huger, W. E., and Kolb, L. (1965). Surg. Gynec. Obstet., 120, 351.

Weston, J. (1967). To be published.

\title{
Effect of Mental Stress on the Fibrinolytic Reactivity to Exercise
}

\author{
J. D. CASH, ${ }^{*}$ M.B., B.SC., M.R.C.P.ED. ; A. G. E. ALLAN,* F.I.M.L.T.
}

Brit. med.7., 1967, 2, 545-543

Nolf (1908) first proposed the existence of a dynamic equilibrium between fibrin deposition (coagulation) and removal (fibrinolysis). This hypothesis was extended by Astrup (1956), who envisaged a continuous deposition and removal of fibrin on the vessel walls as being a normal physiological process. $\mathrm{He}$ further argued that defective fibrinolysis might upset this "haemostatic balance," thus giving rise to excessive fibrin deposition, which could favour thrombosis and also be responsible for some forms of atherosclerosis according to the concept of Rokitansky (1852), elaborated by Duguid (1949, 1955). Subsequent efforts to demonstrate a defective fibrinolytic system in patients with occlusive vascular disease, by single sample analysis, have proved disappointing and controversial (Hume, 1958 ; Lackner and Merskey, 1960 ; Nestel, 1960 ; Ogston, 1962 ; Katz et al., 1963 ; Naimi et al., 1963 ; MacKay and Hume, 1964 ; Fearnley, 1965).

It is possible that some of the present uncertainty arises from the known fact that blood fibrinolytic activity may fluctuate, in any one person, from day to day and throughout the same day (Fearnley et al., 1957 ; Blix, 1961). Unless extreme and prolonged differences exist between patients with occlusive vascular disease and controls, comparison by single estimations could fail to provide satisfactory information. It is also possible that the significant difference between these two groups may not be found by a simple measurement of absolute resting values of fibrinolytic activity, but rather in the capacity of the fibrinolytic system to respond to physiological stimulants, including exercise (Biggs et al., 1947 ; Truelove, 1951 ; Fearnley and Lackner, 1955 ; Billimoria et al., 1959 ; Sherry et al., 1959 ; Ogston and Fullerton, 1961 ; Iatridis and Ferguson, 1963 ; Jang et al., 1964 ; Ogston and McAndrew, 1964 ; Burt et al., \footnotetext{
- From the South-east Scotland Regional Blood Transfusion Research
Laboratories, Royal Infirmary, Edinburgh.
}

1964) and mental anxiety (Macht, 1952; Dreyfuss, 1956 ; Friedman et al., 1958 ; Ogston et al., 1962).

Preliminary observations, made during the early part of a pilot study designed to test this hypothesis, showed that the fibrinolytic response (calculated as a percentage response of the pre-exercise level of the resting euglobulin lysis time) to a standardized submaximal exercise procedure was reproducible in any one individual; there were significant differences between individuals, and it was possible to isolate a group of poor responders (Cash, 1966). It was suggested that these poor responders had a defect in their mechanisms for the production of plasminogen activator to stress, and that they might therefore be more liable to episodes of an imbalance of the coagulationfibrinolysis equilibrium as envisaged by Astrup.

It was assumed that the ability to generate plasminogen activator after exercise was, in part, genetically determined. Subsequent studies, reported in this communication, would indicate that environmental factors, in the form of prolonged mental stress, may also be relevant.

\section{Subjects}

Five male medical student volunteers were studied before, during, and after a resit examination for the 2nd M.B., Ch.B Five male age-matched control volunteers were studied simultaneously-these were not sitting examinations but enjoying their summer vacation.

\section{Materials}

Anticoagulant.-Sodium citrate B.P. $3.8 \%$.

Buffers.- (a) Barbiturate buffer. Modified veronal buffer of pH 7.4 and ionic strength 0.15 (Owren, 1947). (b) Tris buffer. 
A $0.15 \mathrm{M}$ solution of tris-(hydroxymethyl)-amino-methane (Koch-Light Laboratories Ltd., batch No. 11342) adjusted to pH 7.8. (c) Phosphate buffer. $0.1 \mathrm{M}$ at $\mathrm{pH} 7.6$.

Fibrinogen.-A Blombäck and Blombäck (1957) preparation of human fibrinogen with a clottability of $97 \%$ (supplied by Kabi Pharmaceutical Company, batch No. 83164) was used. A $1.5 \mathrm{~g} . / 100 \mathrm{ml}$. solution of fibrinogen in tris buffer was stored in plastic tubes at $-20^{\circ} \mathrm{C}$. After thawing it was diluted to $0.15 \mathrm{~g} . / 100 \mathrm{ml}$. in tris buffer and used for fibrin plates.

Thrombin.-Topical thrombin (Parke Davis and Co., batch No. 031798A) was used. A solution of $50 \mathrm{u} . / \mathrm{ml}$. in tris buffer was prepared for fibrin plates, one of $5 \mathrm{u} . / \mathrm{ml}$. in barbiturate buffer for euglobulin lysis time estimations, and one of $100 \mathrm{u} . /$ $\mathrm{ml}$. in physiological saline for fibrinogen estimations. All these solutions were stored at $-20^{\circ} \mathrm{C}$. in plastic tubes and used immediately after thawing.

Streptokinase.-The preparation produced by Lederle Laboratories (batch No. 2201-66) was used for plasminogen assays. It was diluted to $2,000 \mathrm{u} . / \mathrm{ml}$. in phosphate buffer and stored in plastic tubes at $-20^{\circ} \mathrm{C}$.

Urokinase.-The standard reference preparation $(2,400$ Plough units) produced by Leo Pharmaceuticals, Denmark (batch No. 63062), was used. Solutions of $3 \mathrm{u} . / \mathrm{ml}$. in tris buffer were prepared and stored at $-20^{\circ} \mathrm{C}$. in plastic tubes.

Glassware.-All glassware was siliconized by means of a $3 \%$ solution of I.C.I. M550 silicone in trichloroethylene.

\section{Methods}

Exercise Procedure-All experiments were carried out during the morning, after a light breakfast, in a procedure room at $19-20^{\circ} \mathrm{C}$. Subjects abstained from smoking and excessive exercise on the morning of the experiment, and were required to rest, lying down, for 30 minutes before the initial venepuncture. At the end of the rest period each subject walked at $3.4 \mathrm{~m} . \mathrm{p} . \mathrm{h}$. on a treadmill at 5 degrees elevation for a period of eight minutes. They were required to adjust their stride to 120 paces a minute.
Blood Sampling and Centrifugation.-From a vein in the cubital fossa $9 \mathrm{ml}$. of blood was withdrawn by clean venepuncture with the minimum of venous occlusion into a siliconized syringe. The blood was immediately transferred to a previously cooled centrifuge tube, in melting ice, containing $1 \mathrm{ml}$. of $3.8 \%$ sodium citrate. The first sample remained in the melting ice until the second sample was withdrawn, immediately after the exercise, and then both were centrifuged at 3,400 r.p.m. at $+4^{\circ}$ C. for 20 minutes. The upper third of the plasma was transferred, by means of a siliconized Pasteur pipette, into a precooled plastic tube; euglobulin precipitation was performed immediately.

Euglobulin Lysis Time.-One millilitre of plasma was transferred to a siliconized centrifuge tube in melting ice containing $19 \mathrm{ml}$. of distilled water and $0.18 \mathrm{ml}$. of $1 \%$ acetic acid. The pH was finally adjusted to 6.0 on a Beckman Expanded Scale $\mathrm{pH}$ meter by the dropwise addition of $0.25 \%$ acetic acid. Precipitation time was 10 minutes from the addition of the plasma and was done in melting ice. The euglobulin suspensions were then centrifuged at 3,400 r.p.m. for 20 minutes at $+4^{\circ} \mathrm{C}$. The supernatant was discarded, the inside of the centrifuge tube wiped dry with a tissue, and the precipitate resuspended in $1 \mathrm{ml}$. of barbiturate buffer. Of this euglobulin solution $0.24 \mathrm{ml}$. was transferred in triplicate to 3 by $\frac{3}{8}$ in. ( 7.5 by $1 \mathrm{~cm}$.) siliconized test-tubes and $0.24 \mathrm{ml}$. of thrombin solution added immediately. The test-tubes were placed in a water-bath at $37^{\circ} \mathrm{C}$, and the mean time taken from the addition of thrombin to complete lysis was recorded as the euglobulin lysis time.

Fibrin Plate Assay.-Human fibrin plates were prepared by a modification of the method of Astrup and Müllertz (1952). $10 \mathrm{ml}$. of $0.15 \mathrm{~g} . / 100 \mathrm{ml}$. human fibrinogen in tris buffer was pipetted into a plastic Petri dish, internal diameter $8.8 \mathrm{~cm}$., and clotted immediately with $0.2 \mathrm{ml}$. of thrombin solution on a level table. After 20 minutes, to ensure complete clotting, $0.03-\mathrm{ml}$. samples, in triplicate, of the test material were dropped on to the fibrin films. The plates were incubated at $37^{\circ} \mathrm{C}$. for 24 hours, and the mean product of the perpendicular diameters was taken as a measure of fibrinolytic activity.

Plasma Fibrinolytic Enzyme Activity Before and After a Moderate Exercise Procedure Before, During, and After an Examination

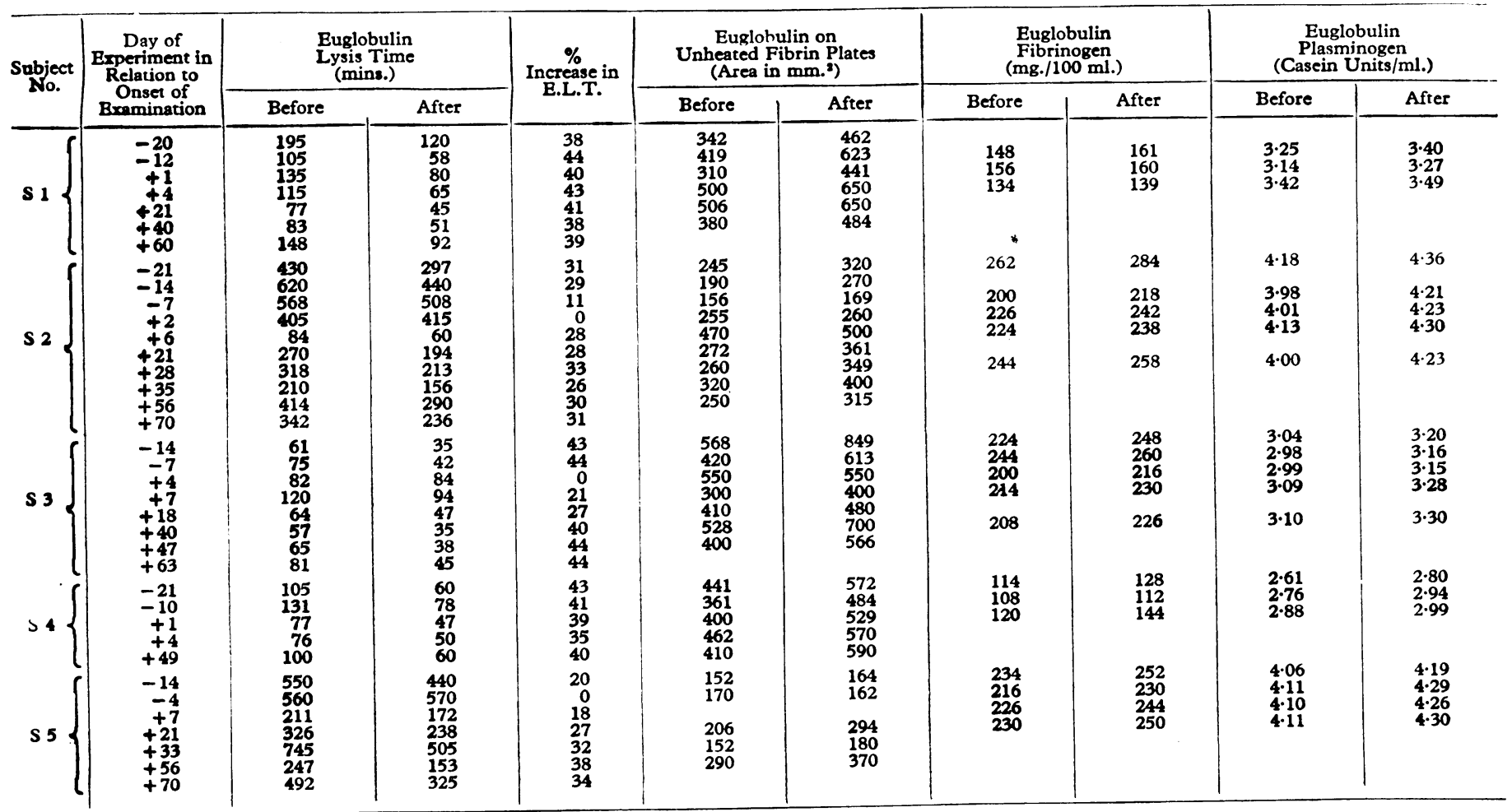


Inhibitor Assay.-Inhibitor assays were based on the method of Blix (1964). Human fibrin plates were prepared as above, but before clotting $1 \mathrm{ml}$. of euglobulin solution diluted in saline was added and thoroughly mixed. A series of four plates were used containing dilutions of $1 / 10,1 / 25$, and $1 / 50$ and control with $1 \mathrm{ml}$. of saline. The test material was urokinase $(3 \mathrm{u}$./ ml. in tris buffer).

Fibrinogen Assay.-The method of Ratnoff and Menzie (1951), as modified by Alkjaersig (1960), was used.

Plasminogen Assay.-The caseinolytic assay of Remmert and Cohen (1949), as modified by Alkjaersig et al. (1959), was used.

\section{Results}

The fibrinolytic response to moderate exercise was assessed as previously (Cash, 1966): if $\mathrm{A}$ and $\mathrm{B}$ represent the resting and postexercise euglobulin lysis times respectively, then $\frac{\mathbf{A}-\mathbf{B}}{\mathbf{B}} \times 100$ was calculated as the percentage response.

The mean percentage response for each unstressed control subject was $39,47,52,50$, and 36 respectively. There was good individual reproducibility throughout the period of study.

The results of the examination candidates are summarized in more detail in the Table and shown graphically (see Chart). Three of the five subjects, immediately before or during the examination period, failed to respond, whereas the remaining two showed no deterioration. This failure of response could not be explained by a fall in plasminogen, a rise in fibrinogen, or the presence of a fibrinolytic inhibitor in the postexercise euglobulin solutions. The results of the euglobulin solutions, tested on unheated human fibrin plates, would further support the view that a production defect of plasminogen activator had occurred.

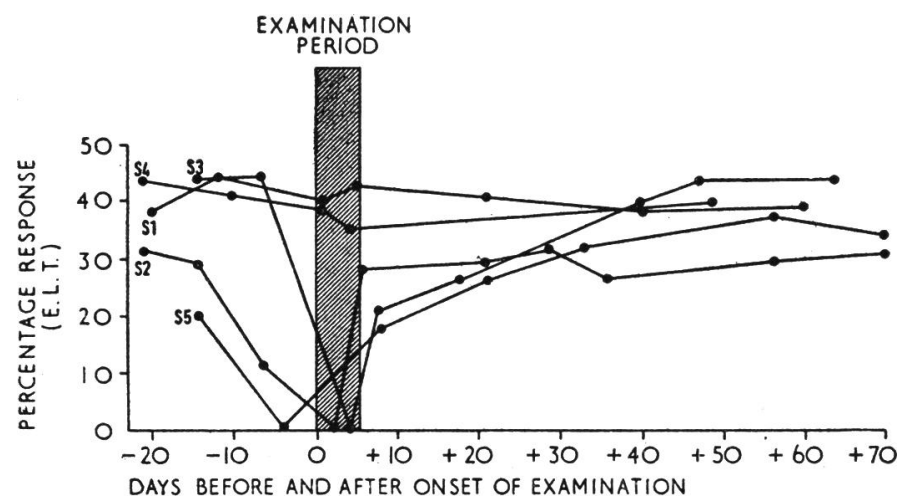

Percentage response (E.L.T.) to moderate exercise in five male subjects before, during, and after an examination.

\section{Discussion}

The role of mental stress in atherogenesis and thrombosis remains controversial. Three mechanisms have so far been postulated : intimal trauma by repeated "whiplash" effects on unsupported parts of the coronary arterial trunks (Hickam et al., 1948 ; Texon, 1957 ; Enos et al., 1962), the production of a hyperlipaemia (Myasnikov, 1958 ; Cardon and Gordon, 1959), and acceleration of coagulation (Schneider, 1951 ; Dreyfuss, 1956 ; Friedman et al., 1958).

Acute anxiety also stimulates the fibrinolytic enzyme system (Macfarlane and Biggs, 1946 ; Truelove, 1951 ; Schneider and Zangari, 1951 ; Ogston et al., 1962 ; Patsch, 1963 ; Ogston, 1964), and it was considered by Cash (1966) that acute mental stress might be a situation which would bring about coagulation-fibrinolysis disequilibrium in those subjects who were "genetically" poor fibrinolytic responders. The results of the present study would indicate that prolonged mental stress may produce a deleterious influence on a normally good fibrinolytic reactivity, and that this effect may continue for some weeks beyond the crisis.

Of no less interest was the observation that two of the five subjects showed no significant change in their fibrinolytic reactivity throughout the period of study. We were unable to convince ourselves that they were less anxious than their three colleagues. There was no correlation between the presence or absence of a deleterious effect and the results of the degree examination.

The mechanism of this effect of prolonged mental stress on fibrinolytic reactivity remains obscure. Acute anxiety stimulates the production of plasminogen activator, and it is suggested that prolonged mental stress may effect a partial exhaustion of the production mechanisms, which has been suggested to arise after prolonged strenuous exercise (Ogston and Fullerton, 1961), and prolonged trauma (Bergentz and Nilsson, 1961 ; Innes and Sevitt, 1964). It might be argued that the absence of a consistent change in the resting levels of plasminogen activator, as measured by the euglobulin lysis time, in those who developed this defect does not substantiate the hypothesis of partial exhaustion of the input system. It is possible, however, that the liver, which controls the removal of plasminogen activator (Fletcher et al., 1964 ; Januszko et al., 1966), can compensate for the reduced input by reduction of plasminogen activator destruction. Also, the production of plasminogen activator which governs the resting level of fibrinolytic activity may be largely contributed to by sources or control systems not directly related to the exercise response phenomenon. This latter concept has support from the work of Amery et al. (1965) in their studies with a niacin compound as a fibrinolytic stimulant.

The results of this study, while adding some new facts on possible relations between fibrinolysis and atherogenesis and thrombosis, support our view that the study of the fibrinolytic reactivity may further enhance an understanding of the poorly understood physiological control mechanisms of the fibrinolytic enzyme system.

\section{Summary}

The fibrinolytic response to a moderate exercise procedure was studied in five student volunteers before, during, and after a degree examination, and in five age-matched unstressed controls. It was demonstrated that mental stress may have a marked deleterious effect on the production of plasminogen activator to exercise. The relevance of these findings is discussed in relation to the aetiology of atherosclerosis and/or thrombosis and the physiological control of the fibrinolytic enzyme system.

We wish to express our thanks to the long-suffering volunteers; to Dr. R. A. Cumming, Director of the South-east Scotland Regional Blood Transfusion Centre, for help and encouragement; and to Professor K. W. Donald, University Department of Medicine, for the generous provision of treadmill facilities. This research programme was supported by a grant from the Scottish Hospital Endowments Research Trust.

\section{REFERENCES}

Alkjaersig, N. (1960). In Proceedings of the Conference on Thrombolytic Agents, April 8-9, 1960, Chicago, Illinois, edited by H. R. Roberts and J. D. Geraty, p. 136. (The Haematology Study Section (U.S.). Public Health Service).

- Fletcher, A. P., and Sherry, S. (1959). F. clin. Invest., 38, 1086.

Amery, A., Vermylen, J., De Vreker, R. A., Vermylen, C., and Verstraete, M. (1965). Amer. F. med. Sci., 249, 66.

Astrup, T. (1956). Lancet, 2, 565.

and Müllertz, S. (1952). Arch. Biochem., 40, 346.

Bergentz, S. E., and Nilsson, I. M. (1961). Acta chir. scand., 122, 21. Biggs, R., Macfarlane, R. G., and Pilling, J. (1947). Lancet, 1, 402. Billimoria, J. D., Drysdale, J., James, D. C. O., and Maclagan, N. F. (1959). Ibid., 2, 471 .

Blix, S. (1961). Scand. F. clin. Lab. Invest., 13, Suppl. No. 58, p. 3. 
Blombäck, B., and Blombäck, M. (1957). Ark. Kemi., 10, 415.

Burt, J. J., Blyth, C. S., and Rierson, H. A. (1964). 'J. Sport Med. (Torino), 4,213 .

Cardon, P. V., jun., and Gordon, R. S., jun. (1959). F. psychosom. Res., 4,5 .

Cash, J. D. (1966). Brit. med. F., 2, 502

Dreyfuss, F. (1956). F. psychosom. Res., 1, 252.

Duguid, J. B. (1949). Lancet, 2, 925.

Enos, W. F., Holmes, R. H., and Beyer, J. C. (1962). Amer. F. Cardiol., 9, 343 .

Fearnley, G. R. (1965). Fibrinolysis, p. 58. London.

Balmforth, G., and Fearnley, E. (1957). Clin. Sci., 16, 645.

and Lackner, R (1955). Brit. 7. Haemat., 1, 189. Fletcher, A. P., Biederman, O., Moore, D., Alkjaersig, N., and Sherry,

Friedman, M., Rosenman, R. H., and Carroll, V. (1958). Circulation, 17, 852.

Hickam, J. B., Cargill, W. H., and Golden, A. (1948). F. clin. Invest., 27, 290 .

Hume, R. (1958). Brit. Heart f., 20, 15.

Iatridis, S. G., and Ferguson, J. H. (1963). F. appl. Physiol., 18, 337

Innes, D., and Sevitt, S. (1964). \%. clin. Path., 17, 1.

Jang, E., Fletcher, B. T., and Bickford, A. F. (1964). Clin. Sci., 27, 9.

nuszko, T. Furman, M., and Buluk, K. (1966). Thrombos. Diathes. haemorrh. (Stuttg.), 15. 554 .
Katz, A. M., McDonald, L., Davies, B., and Edgill, M. (1963). Lancet,

1, 801 ., ackner, H., and Merskey, C. (1960). Brit. F. Haemat., 6, 402.

Macfarlane. R. G., and Biggs, R. (1946). Lancet, 2, 862.

Macht, D. I. (1952). F. Amer. med. Ass., 148, 265.

MacKay, N., and Hume, R. (1964). Scot. med. \%., 9, 359.

Myasnikov, A. L. (1958). Circulation, 17, 99

Naimi, S., Goldstein, R., and Proger, S. (1963). Ibid., 27, 904.

Nestel, P.' J. (1960). Aust. Ann. Med., 9, 234.

Nolf, P. (1908). Arch int. Physiol., 6, 306.

Ogston, D. (1962). Brit. med. 7., 1, 1242

(1964). 3. Psychosom. Res., 8, 219.

and Fullerton, H. W. (1961). Lancet, 2, 730

and McAndrew, G. M. (1964). Ibid., 2, 1205.

McDonald, G. A., and Fullerton, H.' W. (1962). Ibid., 2, 521.

Owren, P. A. (1947). Acta med. scand., 128, Suppl. No. 194.

Patsch, J. (1963). Wien. med. W schr., 113, 537.

Ratnoff, O. D., and Menzie, C. (1951). 7. Lab. clin. Med., 37, 316.

Remmert, L. F., and Cohen, P. P. (1949). 7. biol. Chem., 181, 431.

Rokitansky, C. von (1852). A Manual of Pathological Anatomy. London.

Schneider, R A. (1951). Amer. F. med. Sci., 222, 562.

Sherry, S., Lindemeyer, R. I., Fletcher, A. P., and Alkjaersig, N. (1959). 7. clin. Invest., 38, 810 .

Texon, M. (1957). Arch. intern. Med., 99, 418.

Truelove, S. C. (1951). Clin. Sci., 10, 229.

\title{
Hypophysitis and Hypopituitarism: Report of a Case
}

\author{
R. HUME,* M.B., M.R.C.P.ED., M.R.C.P.GLASG. ; G. HEFIN ROBERTS, $\dagger$ M.B., B.SC., M.C.PATH., D.PATH.
}

So far as we are aware, anterior hypophysitis has been described only once previously (Goudie and Pinkerton, 1962). It seemed of interest, therefore, to report a further case in which the patient, a known case of pernicious anaemia, was found at necropsy to have not only hypophysitis but also chronic atrophic gastritis, focal lymphocytic thyroiditis, and adrenal atrophy.

\section{Case Report}

A nulliparous spinster aged 74 who had an uneventful menopause at the age of 50 was first admitted to the Southern General Hospital in June 1963, when a diagnosis of pernicious anaemia was made on the basis of a macrocytic anaemia, megaloblastic erythropoiesis on sternal marrow examination, histamine-fast achlorhydria, low serum vitamin-B $B_{12}$ level $(25 \mu \mu \mathrm{g} . / \mathrm{ml}$.), and a normal response to the administration of cyanocobalamin. At that time extreme pallor of the skin was remarked upon, and this continued to be a striking feature even when the haemoglobin had returned to normal. She was observed as an outpatient until August 1964, and, though haematologically normal, never regained her former energy. On one occasion hypopituitarism had been suggested to account for her appearance. This possibility had not been investigated further.

On 6 February 1966 she was readmitted to the Southern General Hospital, having been found unconscious at home. During the preceding three weeks she had become progressively more drowsy and mentally confused. Promazine had been prescribed two days before admission. The clinical features of note were extreme pallor and waxy appearance of the skin in spite of a haemoglobin of $13 \mathrm{~g} . / 100 \mathrm{ml}$. Head hair was fine and dry and body hair was scanty. Skin temperature was $94.8^{\circ} \mathrm{F}$. $\left(34.9^{\circ} \mathrm{C}\right.$.) and the blood pressure $70 \mathrm{~mm}$. Hg systolic ; the diastolic pressure was not recordable. Serum electrolyte measurements revealed a low sodium and chloride level ( $\mathrm{Na} 122 \mathrm{mEq} / \mathrm{l} ., \mathrm{Cl} 80 \mathrm{mEq} / \mathrm{l}$.) and normal potassium $(4.3 \mathrm{mEq} / \mathrm{l}$.). Serum urea was raised $(73 \mathrm{mg} . / 100 \mathrm{ml}$.) and blood sugar level normal (94 mg./100 ml.). The electrocardiogram revealed QRS, ST, and T changes compatible with hypothyroidism.

In view of the clinical picture suggesting hypopituitarism treatment was begun with hydrocortisone $100 \mathrm{mg}$. intravenously

* Consultant Physician, Southern General Hospital, Glasgow S.W.1. t Consultant Pathologist, Southern General Hospital, Glasgow S.W.1. eight-hourly and triiodothyronine $10 \mu \mathrm{g}$. twice daily. Next day the patient was rousable, the skin temperature had returned to $97.2^{\circ} \mathrm{F}$. $\left(36.2^{\circ}\right.$ C.). and the systolic blood pressure was $100 \mathrm{~mm} . \mathrm{Hg}$. Progress was continuing satisfactorily; the patient had become conscious but was still irrational, her temperature was normal, and the blood pressure $120 / 70 \mathrm{~mm}$. $\mathrm{Hg}$, when suddenly on 11 February she died, five days after admission.

\section{Necropsy Findings}

The body was that of a well-nourished pale old woman; body hair distribution did not appear grossly abnormal for a woman of 74. Internally the relevant findings were confined to the lungs, pituitary, adrenals, stomach, and thyroid.

The left lung was dark, firm, and heavy (580 g.); there was confluent bronchopneumonia of the lower lobe and along the posterior margin of the upper lobe.

The pituitary was a small flat organ approximately one-third the normal size and covered with a slightly thickened capsule. Both adrenals were atrophied (combined weight $5 \mathrm{~g}$.) and deeply embedded in periadrenal fat. The thyroid was slightly atrophied; both lobes were finely nodular and showed numerous small gritty foci of calcification.

The mucosa of the body of the stomach was severely atrophied, the pyloric mucosa looked normal, and the uterus and ovaries were normal for a woman of her age.

\section{Histological Report}

Pituitary (Figs. 1 and 2).-The pars posterior is normal and the capsule shows fibrous thickening. The pars anterior is less than one-quarter of its normal size and shows lymphocytic infiltration, acinar atrophy, and fibrosis. The lymphocytic infiltration is heavy and diffuse; only the occasional plasma cell is present; no giant cells can be seen. The cellular infiltration is particularly heavy around groups of atrophied acini. Though a few small dense focal aggregates of lymphocytes are present, no true follicles with active germinal centres are seen. Only scattered groups of acini remain-some large, others small. In some areas the glandular tissue consists only of scattered single epithelial cells surrounded by 